\title{
Barley Yellow Dwarf Virus Confirmed in Argentine Bahiagrass in Northeastern Florida ${ }^{1}$
}

\author{
J. Breman, J. DeValerio, A. Gevens, R. Cullen and W. Bird²
}

\section{Introduction}

Bahiagrass (Paspalum notatum, Flügge) is used extensively for pasture, hay, turf, and roadside cover in Florida. Few diseases other than the wet season Dollar Spot (Sclerotinia homoeocarpa, F.T. Benn) and Ergot (Claviceps spp.) impact the health of Argentine bahiagrass. Recently, however, an intense reddening and purpling of leaves accompanied by stunted growth was observed in certain portions of Argentine bahiagrass pastures in Northeast Florida. Previously, such symptoms were attributed to abiotic stresses, such as nutrient deficiency, waterlogging, and/or temperature. Below we show that stunted plant growth accompanied by purple or red leaves occurred on plants infected by Barley Yellow Dwarf Virus (BYDV). This is unusual because viruses rarely cause major diseases of pasture grasses and minor virus infections often go unnoticed since they typically do not lead to plant death or stand loss.

\section{Pathogen and Hosts}

There have been occasional reports of BYDV in crops of wheat and oats grown in Florida. Significant epidemics were observed in the Florida panhandle in
1949, 1956, and 1959, and from 1991 to 1994. BYDV, a luteovirus, has five known species that are spread only by aphids that feed on infected crops. BYDV is not transmitted by mechanical means, by contact between hosts, by seeds, or by pollen. Aphids acquire the virus through feeding on a diseased plant and then transmit it to other susceptible cereal and/or grass species (ie: Italian ryegrass) when they continue feeding. Once aphids acquire the virus, they remain infectious (persistent) for the rest of their lives. Several aphids can vector BYDV, however, the most common ones include English grain aphid (Macrosiphum (Sitobion) avenae), bird cherry-oat aphid (Rhopalosiphum padi), corn leaf aphid (Rhopalosiphum maidis), and green bug (Schizaphis graminum). The virus members of this genus can infect most cereals and numerous grasses, often without causing disease symptoms. The expression of symptoms by infected plants depends upon the cultivar, virus strain, time of infection, and environmental conditions.

1. This document is PP252, one of a series of the Plant Pathology Department, Florida Cooperative Extension Service, Institute of Food and Agricultural Sciences, University of Florida. Original publication date April 2008. Visit the EDIS Web Site at http://edis.ifas.ufl.edu.

2. J. Breman, county extension director, Union County; J. DeValerio, extension agent, Bradford County; A. Gevens, assistant professor, Plant Pathology Department; R. Cullen, senior biological scientist, Plant Pathology Department; W. Bird, former extension agent, Bradford County; Florida Cooperative Extension Service, Institute of Food and Agricultural Sciences, University of Florida, Gainesville, 32611. 


\section{Symptoms in 'Argentine' Bahiagrass}

'Argentine' is a selection of tetraploid bahiagrass introduced into Florida from Argentina in 1945. It has wider leaves than 'Pensacola,' 'Tifton 9,' and other diploid cultivars. Argentine is well adapted to moist flatwood soils, where it is often grown for pasture and hay production. It has also been widely planted in the sod trade.

Patches of bahiagrass with purple or red colored leaves were recently observed in a 10 -acre pasture on flatwood soil located in Northeast Florida (Bradford County). Over a period of two years, the affected patches expanded extensively. In addition to the leaf discoloration, plants in these patches appeared stunted (Fig. 1) with a height of approximately half that of nearby healthy bahiagrass (Fig. 2). The distribution of the disease in a field depends on the pattern of aphid movement and feeding. In Pennsylvania, BYDV commonly occurs in small patches ranging from 1 to $5 \mathrm{ft}$ in diameter. It is also likely that the extreme drought stress influenced the expression of viral symptoms and may have impacted symptom development and observable disease distribution.

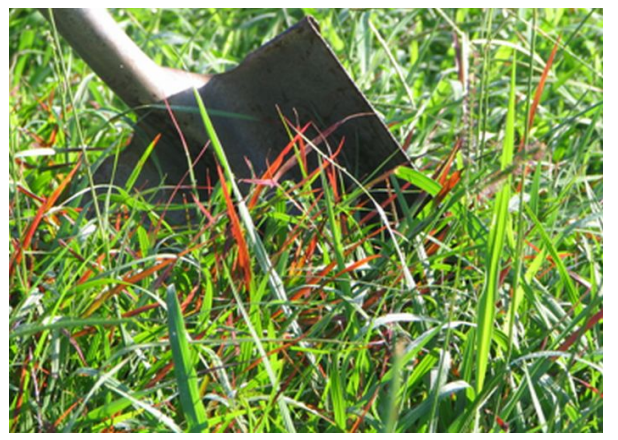

Figure 1. Purpling and stunting symptoms of Barley Yellow Dwarf Virus on 'Argentine' bahiagrass. Approximately 10 acres of symptomatic pasture grass was observed in Bradford County, Florida.

\section{Diagnosis in Argentine bahiagrass}

Several parameters of bahiagrass patches exhibiting red to purple leaves and stunted growth (symptomatic) were systematically compared to those of healthy patches (asymptomatic). These parameters included insect damage to the roots,

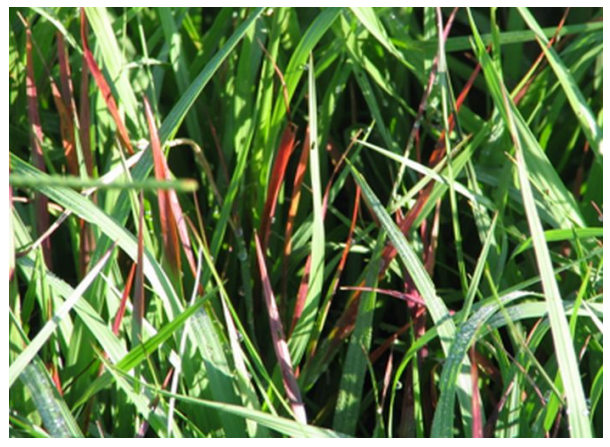

Figure 2. Close up of purpling and stunting symptoms of Barley Yellow Dwarf Virus on 'Argentine' bahiagrass

phosphorous deficiency, and nematode presence in soil from bahiagrass roots.

Roots of both asymptomatic and symptomatic patches had sustained no insect or mole cricket damage when patches of turf were turned over with a shovel.

Phosphorous deficiency, which can cause leaf reddening or purpling, was tested by collecting both composite soil samples (a total of 12) and plant tissue of both asymptomatic and symptomatic bahiagrass. The soil phosphorous was 33 parts per million (ppm) higher for symptomatic plants than for asymptomatic (Table 1). The leaf tissues of symptomatic and asymptomatic plants contained similar concentrations of phosphorous (Table 2). Thus, we concluded that leaf discoloration was not associated with a deficiency in phosphorous. Moreover, none of the other essential elements tested appeared to be deficient in the discolored plants (Table 2).

Since stunting can be caused by nematode injury, soil from the rhizosphere of healthy and affected plants was collected and analyzed for populations of plant parasitic nematodes. Results of the testing by the UF/IFAS Nematode Lab indicated that nematodes are unlikely to cause the differences in bahiagrass health. Nematode populations from both symptomatic and asymptomatic plants were within the moderately damaging range (Table 3).

Symptoms of BYDV may vary depending upon the stage of the grass when the infection occurred and on other plant stress factors. Soon after BYDV is transmitted to the plant by an aphid, the virus moves into the roots, replicates, and disrupts the normal process of material transport from root to leaf. As a 
Table 1. Soil micronutrients and the UF/IFAS Extension Soil Test Lab rating.

\begin{tabular}{||l|l|l||}
\hline \hline \multicolumn{1}{|c|}{ Asymptomatic } & \multicolumn{1}{c||}{$\begin{array}{c}\text { Symptomatic } \\
\text { (purpled \& stunted) }\end{array}$} \\
\hline $\mathbf{p H}$ & 5.8 & 6.0 \\
\hline Phosphorous & $45 \mathrm{ppm}$ (high) & $78 \mathrm{ppm}$ (very high) \\
\hline Potassium & $39 \mathrm{ppm}$ (medium) & $29 \mathrm{ppm}$ (low) \\
\hline Magnesium & $61 \mathrm{ppm}$ (very high) & $88 \mathrm{ppm}$ (very high) \\
\hline Calcium & $658 \mathrm{ppm}$ (very high) & $922 \mathrm{ppm}$ (very high) \\
\hline Copper & $0.64 \mathrm{ppm}$ (sufficient) & $0.77 \mathrm{ppm}$ (sufficient) \\
\hline Manganese & $4.61 \mathrm{ppm}$ (sufficient) & $4.04 \mathrm{ppm}$ (sufficient) \\
\hline Zinc & $9.74 \mathrm{ppm}$ (above response) & $9.75 \mathrm{ppm}$ (above response) \\
\hline \hline
\end{tabular}

Table 2. Plant tissue micronutrients expressed on a dry matter basis, from the UF/IFAS Extension Soil Test Lab with ratings for Bahiagrass from selected references.

\begin{tabular}{||l|l|l||}
\hline \hline & \multicolumn{1}{|c||}{ Asymptomatic } & \multicolumn{1}{|c||}{$\begin{array}{c}\text { Symptomatic } \\
\text { (purpled \& stunted) }\end{array}$} \\
\hline Phosphorous & $0.36 \%$ (adequate) & $0.30 \%$ (adequate) \\
\hline Potassium & $2.19 \%$ (adequate) & $1.53 \%$ (adequate) \\
\hline Magnesium & $0.31 \%$ (adequate) & $0.30 \%$ (adequate) \\
\hline Calcium & $0.28 \%$ (adequate) & $0.35 \%$ (adequate) \\
\hline Copper & $1.66 \mathrm{ppm}$ (low) & $0.12 \mathrm{ppm}$ (low) \\
\hline Manganese & $107.60 \mathrm{ppm}$ (adequate) & $78.70 \mathrm{ppm}$ (adequate) \\
\hline Zinc & $41.39 \mathrm{ppm}$ (adequate) & $28.10 \mathrm{ppm}$ (adequate) \\
\hline Iron & $16.44 \mathrm{ppm}$ (low) & $11.21 \mathrm{ppm}$ (low) \\
\hline Boron & $20.23 \mathrm{ppm}$ (adequate) & $19.27 \mathrm{ppm}$ (adequate) \\
\hline \hline
\end{tabular}

Table 3. Nematode assay report from the UF/IFAS Nematode Lab with nematode numbers and risk level.

\begin{tabular}{||l|l|l||}
\hline \hline & Asymptomatic & $\begin{array}{c}\text { Symptomatic } \\
\text { (purpled \& stunted) }\end{array}$ \\
\hline Hemicroconemoides & 344 (moderate) & 376 (moderate) \\
\hline Mesocriconema & 793 (moderate) & 1017 (moderate) \\
\hline \hline
\end{tabular}

result, plants are stunted, leaves turn red or purple, and the overall health of the plant is compromised. Since this disease was previously observed in the panhandle of FL, we collected fresh samples of both symptomatic and asymptomatic bahiagrass (6 from each group) and subjected them to Enzyme-Linked-Immuno-Sorbent Assay (ELISA) to determine the presence or absence of BYDV. The Argentine bahiagrass samples exhibiting purpling and stunting were found to be infected with BYDV-MAV. This strain is usually transmitted by Macrosiphum (Sitobion) avenae (grain aphid), and rarely by bird cherry-oat aphid, corn leaf aphid, or greenbug. Asymptomatic plants tested by ELISA were negative for BYDV-MAV.

\section{Disease Management}

A perennial crop such as bahiagrass could be exposed to BYDV because it is vectored by aphids from susceptible small grains (such as Italian ryegrass, oats, and wheat) during the cool season. Currently, the UF/IFAS Extension recommendation for growing susceptible small grains is to seed later in the fall when aphid populations and movement have declined. This reduces the BYDV infection, which can cause severe losses if it begins in young seedlings. Attempts to control aphid populations with pesticides have not been effective and are not recommended. 
Drought stress may increase the severity of viral symptoms in plants. Therefore, irrigating Argentine bahiagrass during drought periods may limit virus symptoms. However, this may not be an economically viable alternative for producers.

For severely infected pastures, such as the one we observed, the only practical alternative is to plow the grass under and then to replant the field with BYDV-resistant grasses. It should be noted that, at this time, symptoms associated with BYDV have not been observed on other bahiagrass cultivars in Florida, nor have they been widespread in Argentine bahiagrass pastures throughout the state of Florida.

\section{Selected References}

Blount, A.R., G.M. Prine and C.G. Chambliss. 2005 Annual ryegrass.SS-AGR-88, Agronomy Department, Florida Cooperative Extension Service, Institute of Food and Agricultural Sciences, University of Florida. Online. Verified 26 December, 2007. (http://edis.ifas.ufl.edu/AG104).

Büchen-Osmond, C. Ed. 2006. ICTVdB Management. 00.039.0.01.002. Barley yellow dwarf virus-MAV. In: ICTVdB - The Universal Virus Database. Version 4. Columbia University, New York, USA.

De Wolf, E. 2002. Barley Yellow Dwarf. Field Crop Disease Facts. Pennsylvania State University. Online. Verified 2 April 2008 http://pubs.cas.psu.edu/FreePubs/pdfs/ul206.pdf. .

Fauquet, C. M., Mayo, M. A., Maniloff, J., Desselberger, U., and Ball, L. A. (Eds.). 2005. Virus Taxonomy, VIIIth Report of the International Committee on the Taxonomy of Viruses. Elsevier Academic Press.

Kincheloe, S., R.A. Hoyum, F.J. Reed, P.J. Bergeau, H.D. Morris, H.F. Reetz, V.W. Case, and M.E. Sevey. 1988. [ $2^{\text {nd }}$ Edition] Efficient fertilizer use. IMC Fertilizer Inc., Mundelein, IL. P. 219.

Kucharek, T., Purcifull, D., and E. Hiebert. 2003. Viruses that have occurred naturally in agronomic and vegetable crops in Florida. PP/PPP7, Plant Pathology Department, Florida Cooperative Extension Service, Institute of Food and Agricultural
Sciences, University of Florida. Online. Verified 26 December 2007. (http://edis.ifas.ufl.edu/PG101).

Newman, Yoana C. 2007. Bahiagrass: A Quick Reference. SS AGR 263, Agronomy Department, Florida Cooperative Extension Service, Institute of Food and Agricultural Sciences, University of Florida. Online. Verified 26 December, 2007. (http://edis.ifas.ufl.edu/AG271).

Silveira, M.L., J.M. Vendramini, L.E. Sollenberger, C.L. Mackowiak, Y.C. Newman. 2007. Tissue analysis as a nutrient management tool for Bahiagrass pastures. Verified 14 January 2008. Online. Verified 14 January 2008. (http://edis.ifas.ufl.edu/SS475).

Wiese, M. V. 1987. Compendium of wheat diseases, second edition. Barley yellow dwarf. APS Press. The American Phytopathological Society. Pp. 70-72. 